June 1993

\title{
Walking in One's Own Shoes
}

Robert Neil Gerstman, D.O.

Thomas Jefferson University Hospital

Follow this and additional works at: https://jdc.jefferson.edu/jeffjpsychiatry

Part of the Psychiatry Commons

Let us know how access to this document benefits you

\section{Recommended Citation}

Gerstman, D.O., Robert Neil (1993) "Walking in One's Own Shoes," Jefferson Journal of Psychiatry. Vol. 11 : Iss. 2 , Article 14.

DOI: https://doi.org/10.29046/JJP.011.2.012

Available at: https://jdc.jefferson.edu/jeffjpsychiatry/vol11/iss2/14

This Article is brought to you for free and open access by the Jefferson Digital Commons. The Jefferson Digital Commons is a service of Thomas Jefferson University's Center for Teaching and Learning (CTL). The Commons is a showcase for Jefferson books and journals, peer-reviewed scholarly publications, unique historical collections from the University archives, and teaching tools. The Jefferson Digital Commons allows researchers and interested readers anywhere in the world to learn about and keep up to date with Jefferson scholarship. This article has been accepted for inclusion in Jefferson Journal of Psychiatry by an authorized administrator of the Jefferson Digital Commons. For more information, please contact: JeffersonDigitalCommons@jefferson.edu. 


\title{
Walking in One's Own Shoes
}

\author{
ILLNESS IN THE ANALYST: \\ IMPLICATIONS FOR THE TREATMENT RELATIONSHIP \\ Harvey J. Schwartz, M.D. and Ann-Louise S. Silver, M.D., Editors \\ International Universities Press, New York \\ 1990, 347 pp., \$42.50.
}

\section{Robert Neil Gerstman, D.O.}

Medical students are taught basic sciences and clinical sciences during their undergraduate training. Psychiatrists and other physicians are taught patient care in their residency programs. In medical education, the topic of illness in the physician is rarely discussed. The differences between doctors who have personally experienced a serious medical illness and those who have not usually go unexamined. It is as if walking in our patient's shoes is a topic so overwhelming that it has become taboo.

Psychiatry differs from other disciplines because the psychiatrist is more dependent upon his own life experience and its role in the transferential relationship. In Illness in the Analyst, Drs. Schwartz and Silver, both survivors of serious illnesses, explore how this experience can affect both physician and patient. The book is a collection of articles written by different authors examining a variety of aspects of this rarely explored topic.

The first section, Personal Reflections, explores how serious illness affects the analyst. This section is divided into three chapters, the first being "The Analytic Attitude in the Service of Denial" by Jacob A. Arlow, M.D., where he reported:

How life-threatening illness in the analyst may affect patients constitutes a serious issue of technique ... keeping in mind the effect upon the transference, the analyst has to decide how, what, and when to tell the patient of his illness. (page 21)

Similarly, Normund Wong, M.D., discussed in his chapter, "Acute Illness in the Analyst," the effect of an extended hospitalization with no advanced warning upon him:

I accepted how close I had come to death and was in touch with my feelings of emotional pain and suffering which I had stoically suppressed ... I acknowledged my mixed feelings of dependency, disappointment,

Robert Gerstman, D.O. is a PGY-III psychiatry resident at Thomas Jefferson University Hospital in Philadelphia. 
and anger at my gastroenterologist at the outcome of a seemingly benign procedure gone awry. (pp. 38-39)

Francoise Davione, Ph.D. did not tell any of her patients about her anergy and anorexia but her patients picked up on her deteriorating health and incorporated it into their delusional systems as a way of maintaining a bond with her. She discussed in her chapter, "Delusion as a way of Knowledge," how a particular patient's changing delusions coincided with the discovery and then surgical intervention for her ovarian cyst despite her not discussing any specifics with him. These chapters served as introductory statements for the theme of this book; that the personal experiences of the analyst may have far greater influence on the course of therapy than expected.

The second section, Clinical Implications, continues this theme on a broader level, discussing different scenarios over seven chapters. Paul A. Dewald, M.D., wrote in his chapter, "Serious Illness in the Analyst: Transference, Countertransference \& Reality Responses-\& Further Reflections," how his own denial of the extent of his illness affected the way his absence was announced to his patients while he was away:

I asked my secretary to call and inform them I was ill in the hospital but hoped to be back to work in the following week . . . when it became obvious that I would not be going back to work I asked her to again call each patient with the message that I was still in the hospital but hoped to be back at work the following week ... the increasing seriousness of my illness made it manifestly impossible to maintain the denial and at that point the message to the patients was that I would be away from my practice indefinitely and would contact them when I was ready to return. (page 77)

By his acknowledgement of his resistance to the severity of illness he was able to better understand the torment of his patients. Similarly, Sander M. Abend, M.D., discussed in "Serious Illness in the Analyst: Countertransference Considerations" the issue of how much information to tell the patient about one's leave of absence for an indefinite period of time:

The essential argument to be considered asserts that while too much factual information may inhibit the range of expression of patients' reactions ... too little information may, for some patients at least, prove too burdensome, thus serving to limit the analysis of transference fantasies. (page 105)

The remaining chapters in this section centered on how the illnesses of the analysts directly affected their patients. Harvey J. Schwartz, M.D., reported in his chapter, "Illness in the Doctor: Implications for the Psychoanalytic Process," that for patients, "becoming seriously ill activates powerful fantasies of punishment, mutilation and abandonment." (page 115) Ann Louise Schlesinger Silver, M.D., in her chapter "Resuming the Work with a Life-Threatening Illness-\& Further Reflections," remarked that "people are seeking me out for analytic treatment because they have heard that I had come through a harrowing experience of illness." (page 169) In the 
chapter by Richard Lasky, Ph.D., "Keeping the Analysis Intact When The Analyst Has Suffered a Catastrophic Illness: Clinical Considerations," regarding the limiting of information told to his patients, he wrote, "one of my concerns was that giving patients the specific information that I was ill would channel (or even dictate) their fantasies too narrowly." (page 182) Susan G. Lazar, M.D., reflected on the effect that her multiple pregnancies, which unfortunately included multiple miscarriages, had on her patients. She acknowledged that her situation was different from the other life-threatening scenarios discussed in this book, however she likened her situations to theirs because "it is nonetheless an unwelcome intrusion on the patient while being a deeply personal meaningful event for the analyst." (page 199)

The last chapter in this section was by Amy Lichtblau Morrison, M.S.S.W., entitled, "Doing Psychotherapy While Living with a Life-Threatening Illness," where she questioned whether a new patient should be told of her cancer history before starting treatment. "What if there's a history of and vulnerability to loss as occurred recently with a prospective new patient who at an early age lost his mother to breast cancer?" (pp. 246-247) She answered her own question by making the observation that "we need to consider and balance what is gained or lost in the adherence to a stance of analytic anonymity when the therapist is dealing with a serious or life-threatening illness." (page 248)

The third and last section, Death of the Analyst, explores how the death of an analyst affects analysands who were in therapy and those who have already completed therapy. David A.S. Garfield, M.D., wrote in "Manifestations of Grief and Grievance: A Therapist's Response to an Analyst's Death" about the difficulty he had mourning for his analyst because of the father transference he placed upon him. (page 265)

Thomas Wolman, M.D., wrote in "The Death of the Analyst in the Posttermination Phase of Analysis: Impact and Resolution" that the death of the analyst highlights the importance of the post-termination phase of analysis, which is generally characterized by a work of mourning for the analyst. This resolution requires the patient to give up the analyst as object and to replace him or her with the formal function designated by the title 'analyst'. He discusses how the death of the analyst in the post-termination phase can serve to promote the final detachment from him or her as an object. (page 296) Similarly, Abraham Freedman, M.D., discussed these themes in "Death of the Psychoanalyst as a Form of Termination of Psychoanalysis."

Finally, Stephen K. Firestein, M.D., in his chapter, "Death of the Analyst: Termination, Interruption, What?", attempted to summarize the preceding chapters by comparing the illness of the analyst to the surgeon collapsing in the middle of the operation. "Whatever is done for the surgeon, no one for a second can forget the plight of the patient, and colleagues immediately step in to substitute and meet the patient's need for care." (page 337) He also remarks on the worst case scenario of an analyst dying is that of one who has no family or staff to quickly advise patients of the news. (page 338)

The one shortcoming of this text is that the various authors make references to each other's chapters which makes for difficult reading at times. Otherwise, Drs. Schwartz and Silver make a valuable contribution to the psychoanalytic literature by organizing a collection of articles on a topic seldom discussed. 